Ana Dili Eğitimi Dergisi
Journal of Mother Tongue Education
ADED - JOMTE
www.anadiliegitimi.com

\title{
İlköğretim Bölümü Öğretmen Adaylarının Kitap Okuma Alışkanlıklarının Değerlendirilmesi
}

\author{
Ercan $A R I^{*}$ \\ Mehmet Kaan DEMiR ${ }^{* *}$
}

Özet

\begin{abstract}
Bu araştırma Çanakkale Onsekiz Mart Üniversitesi Eğitim Fakültesi Illköğretim Bölümü 3. sınıf öğretmen adaylarının kitap okuma alışkanlıklarını ortaya koymayı amaçlamaktadır. Susar Kırmızı (2012) tarafından geliştirilen tutum ölçeğin kullanıldığı araştırmaya 278 öğretmen adayı katılmışır. Araştırma sonucunda ilköğretim öğretmen adaylarının kitap okumaya ilişkin tutumlarının cinsiyet değişkenine göre anlamlı olarak değiştiği anlaşıımıştır. Bununla birlikte ilköğretim öğretmen adaylarııın kitap okumaya ilişkin tutumlarının öğrenim gördükleri anabilim dalı, öğretim türü, aile geliri, yaşanılan yerleşim yeri türü, anne eğitim durumu ve baba eğitim durumu değişkenlerine göre ise anlamlı olarak farklılaşmadığı ortaya çıkmıştır.
\end{abstract}

Anahtar Sözcükler: illköğretim, öğretmen adayı, kitap okuma, tutum.

\section{Assessing Reading Habits of Student Teachers' at Department of Elementary Education}

\begin{abstract}
This research aims to explore the teachers' book reading habits at Çanakkale Onsekiz Mart University, Faculty of Education, and Department of Elementary Education. Attitude scale developed by Susar Kırmızı (2012) was conducted to 278 teacher candidates. As a result, it is identified that student teachers teachers' book reading habits changed significantly according to gender. However there were no significant differences according to subject area, education type, family income, place of residence, education level of the mother and the father.
\end{abstract}

Keywords: elementary education, teacher candidate, book reading, attitude

\footnotetext{
*Yrd. Doç. Dr. Çanakkale Onsekiz Mart Üniversitesi, Eğitim Fakültesi, Illköğretim Bölümü. Çanakkale. e-posta: ercanari@hotmail.com

${ }^{* *}$ Yrd. Doç. Dr. Çanakkale Onsekiz Mart Üniversitesi, Eğitim Fakültesi, İlköğretim Bölümü. Çanakkale. e-posta:mkdemir2000@yahoo.com
} 


\section{Giriş}

Medeniyet, insanlığın kitaptan hafızasıdır. Kitabın şöyle bir tarifi vardır: "Bir konu veya bilgi alanı üzerine ya da belirli bir amaç için yazıımış veya basılmış kâğıtların bir araya getirilmiş ciltli yahut ciltsiz şekli, bilgiyi yazılı olarak başkalarına nakletmek, aktarmak için bulunmuş vasıtadır" (Yeni Türk Ansiklopedisi,1985). Kitaplara kimlik kazandıran okumak ise, yazılı olan bir metnin içindeki duygu, düşünce ve iletileri anlamak; ayrıca yazarın bunları nasıl organize ettiğini ve duygularını dilin sunduğu imkânlarla nasıl aktardığını kavramaktır. Okuma alışkanlığı ise "Bireyin bir gereksinim ve zevk kaynağı olarak algılaması sonucu okuma eylemini yaşam boyu, sürekli, düzenli ve eleştirel bir biçimde gerçekleştirmesidir (Yılmaz, 1998).

Kuşkusuz bilgi sahibi olmanın gezme, eğitim programlarına katılma ve televizyon izleme gibi çok çeşitli yolları vardır. Ancak bilgi sağlamanın dışında farklı birtakım kazanımlara da yol açması nedeniyle okuma bu yöntemlerin en etkili ve verimli olanıdır. Okuma bireyin bilgi edinebilmesi ve öğrenmesi sağlar. Bunun yanında okuma bireyin; (Koç ve Müftüoğlu, 2008, s. 62)

- Davranış ve başkalarıyla ilişkilerini yönlendirir;

- İç dünyasını zenginleştirir;

- Bakış açısını genişletir;

- Çevresine önyargısız, yansız ve hoşgörülü bakmasını sağlar;

- Beğeni düzeyini artırır;

- Düşünme ve yaratma özgürlüğü ile değerlendirme alışkanlığı kazanmasını sağlar.

Okuma, yalnızca öğrencilerin değil, herkesin geniş bir bilgi evrenine açılması, düşünce ve duyarııığını geliştirmesi, toplumla sağlıklı bir iletişime girmesi için başvurması gereken etkili bir öğrenme aracıdır (Sever, 1997: 14). Ülkemizde serbest okuma etkinlikleri, çocuk ve gençleri okumaya teşvik çalışmaları; Avrupa'da yapılan çalışmalara ve eğitim bilimindeki gelişmelere paralel bir şekilde başlamıştır. 19. yüzyıldan itibaren toplumun her kesimine okumayı sevdirme gayreti içine girilmiş; bu konuda özellikle süreli yayınlar araç olarak kullanılmıştır (Sünbül ve diğ., 2010).

Eğitim sisteminin önemli görevlerinden birisi de, öğrencilere okuma alışkanlığı kazandırmaktır. Okumak, insanda olumlu ilgilerin ve etkilerin uyanıp gelişmesine yardım etmekte ve kendi kendini eğitmesine katkıda bulunmaktadır (Tezcan, 1983). Ayrıca okuduğunu tam ve doğru olarak anlama, okuyucunun okunanları yaşantı ile değerlendirme, onları dil ve düşünce yönünden eleştirel yargılama gibi bazı alışkanlıkların kazandırılmasını da gerektirmektedir (Akçamete, 1989). Kitap okumanın bu etkileri dışında Kanada'da öğretmen adaylarının okuma alışkanlıkları ile yazma becerisi arasında yapılan bir çalışmada, okuma alışkanlığı olan adayların daha iyi yazdıkları görülmüştür (Benevides, 2006). Ne var ki, ülkemizde özellikle çocukların ve gençlerin okuma alışkanlığının gittikçe azaldığı görülmektedir. Kitap okuyanların sayısı 1965'te \%27, 1980'de \%5.7, 1990 'da \%2.5, 1997 'de \%3.5 olarak belirlenmiş ve $1965^{\prime}$ deki oranın onda birine gerilediği ortaya konulmuştur (Özen, 1998). Bir başka araştırmada da Japonların bir yılda ortalama 25, İsveçlilerin 10, Fransızların ise 7 kitap okuduğu; ülkemizde ise bir yılda altı kişiye yalnızca bir kitap düştüğü saptanmıştır (Odabaş, 2005).

Amerika'da yapılan bir araştırmaya göre de çocukların erken yaşta kitap okumayla tanışmaları, okuma alışkanlığının edinilmesinde etkili olduğu belirlenmiştir (Duros, 2009). Diğer bir çalışmada ise altıncı sınıf öğrencilerinden oluşan 51 kişi ile yapılan görüşmede öğrenciler okuma alışkanlığının edinilmesinde öğretmenlerin etkili olduklarını belirtmişlerdir (Myette, 2006). Wilson'ın yaptığı çalışmaya göre ailelerin günlük gazete okuma alışkanlıklarının lise öğrencilerinin de okuma alışkanlıklarını etkilediğini göstermiştir (Wilson, 2007). Baccus (2004), öğretmenlerin kitap okuma ile ilgili deneyimleri, öğrencileri yönlendirmeleri, öğrencilerin kitap okumaya yönlenmeleri ve motive olmalarında etkili olduğunu tespit etmiştir. Janes'in yaptığı çalışmaya göre ailelerin okuma alışkanlığı konusunda bilgilendirilmesi sonucunda, bu ailelerin çocuklarının da kitap okumaya karşı ilgi duyduklarını belirlemiştir (Netherland, 2004; Janes, 2008;). Yapılan bu araştırmalar okuma alışkanlığının çocuklara veya öğrencilere verilmesi gerektiği ve bunun için gerek ebeveynler gerekse öğretmenlerin birer model olmaları zorunluluğunu ortaya koymaktadır. Arıcı'nın (2005: 61) iki bin öğrenci üzerinde yapmış olduğu araştırmada öğrencilerin \%57,3'ü kitap okuma fikrini öğretmeninden aldığını söylemektedir. Aynı araştırmada kitap okumaya, annemden görerek alıştım, diyenlerin oranı, 
17,9; babamdan diyenlerin oranı 13,4'tür. Öğrencilerin \%35,4'ü ilk kitabını öğretmenin kendilerine verdiğini söylemektedir. Bu araştırma ailelerin kitap okumadığı, çocuklarına iyi bir model olamadıklarını göstermektedir.

Yılmaz'ın (2004:139) öğretmenler üzerinde yapmış olduğu bir araştırma, hiç okumayan ve zayıf okuma alışkanlığına sahip olan öğretmenlerin oranının \%68.5'e ulaştığını göstermektedir. Yani yüz öğretmenden yaklaşık yetmişi, ya okuma alışkanlığına sahip değil, ya da bu konuda model olamayacak kadar zayıf okuyucu konumundadır. Öğrencilerin kitap okuması için onları okumaya teşvik etmesi ve daha da önemlisi onlara çok güzel bir model olması gereken öğretmen, bireylerin zihinsel süreçlerinin hızla geliştiği dönemlerinde, onların okuma alışkanlığını elde etmelerini sağlayacak en etkili kişidir. İyi bir okuyucu olmayan anne, sadece kendi çocukları için kötü bir örnek olmaktadırlar. Ama iyi bir okuyucu olmayan öğretmen, yüzlerce hatta binlerce öğrenciye kötü örnek olmakta ve onların geleceğini olumsuz yönde etkilemektedir (Ungan,2008).

Okuma alışkanlığı kazanma ve bu alışkanlığı sürdürmeyi olumsuz yönde etkileyen önemli etkenlerden biri de teknolojik bağımlılıktır. Söz konusu teknolojilerin başında ise televizyon seyretme ve bilgisayar kullanımı gelmektedir. Bu konuda günümüze kadar yapılan araştırmaların çoğunda toplumun önemli bir kısmının dinlenme vakitlerinin önemli bir kısmını televizyon başında geçirdiği tespit edilmiştir (Aksaçlıoğlu ve Yılmaz, 2007: 9; Ortaş, 2007; Koçal, 2004). Televizyon özellikle okul öncesi dönemlerde çocukların zihinsel gelişimine katkıda bulunabilecek bir araçtır. Çocukların daha yaratıcı olmalarını ve dolayısıyla öğrenim becerilerinin gelişmesini sağlayan televizyon yayınları, aynı zamanda yetişkinlerin bilgi dağarcıklarını zenginleştirmeye yarayan özelliğe de sahiptir. Ancak izleme süresi ve izlenen programın türünde gerekli koşullar sağlanmadığı takdirde televizyon, özellikle çocuklar olmak üzere her yaştan insanın gelişimine, sosyal ilişkilerine ve sağlığına zararlı olabilecek bir araçtır. Gerek bazı yabancı ülkelerde gerekse Türkiye'de yapılan araştırmalar günlük televizyon izleme süresinin gereğinden fazla uzatıldığını göstermekte, bunun da insanın sağlı̆ıını, ilişkilerini ve günlük faaliyetlerini olumsuz yönde etkilediğini kanıtlamaktadır (Lehr, 1981, s. 231; Aksaçlıoğlu ve Yılmaz, 2007: 18).

Aynı şekilde, öğretmen adayları üzerinde yapılan araştırmalarda (Sağlamtunç, 1990; Dökmen, 1994; Balcı, 2003; Filiz, 2004 Saracaloğlu, Yenice ve Karasakaloglu, 2006; Yalınkılıç, 2007; Kurulgan ve Çekerol, 2008; Yılmaz, Köse ve Korkut, 2009; Mavi ve Çetin, 2009; Aslantürk ve Saracaloğlu, 2010) öğrencilerin okuma ilgi ve alışkanlıklarının yeterli olmadığı sonucuna ulaşılmışır. Bu araştırmalar öğretmen adaylarının okuma alışkanlıklarının incelenmesi gerektiğinin ne denli önemli olduğunu ortaya koymaktadır

Bu çalışma; eğitim fakültesi ilköğretim bölümü öğretmen adaylarının sosyo-ekonomik durumları ile kitap okuma alışkanlıkları arasındaki ilişkinin tespit edilmesini ve kitap okuyamama sebeplerini ortaya çıkarmayı amaçlamaktadır.

\section{Araştırma Modeli}

\section{Yöntem}

$\mathrm{Bu}$ araştırma tarama modelinde bir araştırma olarak düzenlenmiştir. Yani araştırmada Çanakkale Onsekiz Mart Üniversitesi Eğitim Fakültesi İlköğretim Bölümü öğretmen adaylarının kitap okuma alışkanlıkları bir tutum ölçek yardımıyla var olduğu şekliyle ortaya konulmaya çalışılmıştır.

\section{Evren-Örneklem}

Araştırmanın evreni Çanakkale Onsekiz Mart Üniversitesi Eğitim Fakültesi Illköğretim Bölümünün 3. sınıflarında öğrenim gören öğretmen adaylarıdır. Bu evren içerisinden rastgele alınan 278 öğretmen adayı örneklem olarak seçilmiştir. Örnekleme ait demografik özellikler Tablo 1'de sunulmuştur. 
Tablo 1. Örneklemi Oluşturan Öğretmen Adaylarının Demografik Özellikleri

\begin{tabular}{|c|c|c|c|}
\hline \multicolumn{2}{|l|}{ Değişkenler } & $f$ & $\%$ \\
\hline \multirow{3}{*}{ Anabilim Dalı (278) } & Sınıf Öğretmenliği & 110 & 39,6 \\
\hline & Okul Öncesi Öğretmenliği & 96 & 34,5 \\
\hline & Fen Bilgisi Öğretmenliği & 72 & 25,9 \\
\hline \multirow[t]{2}{*}{ Cinsiyet (278) } & $\mathrm{K}$ & 224 & 80,6 \\
\hline & $\mathrm{E}$ & 54 & 19,4 \\
\hline \multirow{2}{*}{ Öğretim Türü (278) } & Normal Öğretim & 124 & 44,6 \\
\hline & İkinci Öğretim & 154 & 55,4 \\
\hline \multirow{5}{*}{$\begin{array}{l}\text { Aylık Aile Geliri (TL) } \\
\text { (278) }\end{array}$} & $0-500$ & 32 & 11,5 \\
\hline & $501-1000$ & 62 & 22,3 \\
\hline & $1001-1500$ & 63 & 22,7 \\
\hline & $1501-2500$ & 77 & 27,7 \\
\hline & 2501 ve üzeri & 44 & 15,8 \\
\hline \multirow{5}{*}{$\begin{array}{l}\text { Yaşanılan } \\
\text { Yerleşim } \\
\text { Yeri } \\
(278)\end{array}$} & Köy & 24 & 8,6 \\
\hline & Kasaba & 17 & 6,1 \\
\hline & illçe & 99 & 35,6 \\
\hline & il & 91 & 32,7 \\
\hline & Büyükşehir & 47 & 16,9 \\
\hline \multirow{5}{*}{$\begin{array}{l}\text { Anne } \\
\text { Eğitim } \\
\text { Durumu } \\
(278)\end{array}$} & Okur-yazar değil & 17 & 6,1 \\
\hline & ilkokul & 149 & 53,6 \\
\hline & Ortaokul & 40 & 14,4 \\
\hline & Lise & 53 & 19,1 \\
\hline & Üniversite & 19 & 6,8 \\
\hline \multirow{5}{*}{$\begin{array}{l}\text { Baba } \\
\text { Eğitim } \\
\text { Durumu } \\
(278)\end{array}$} & Okur-yazar değil & 0 & 0 \\
\hline & ilkokul & 96 & 34,5 \\
\hline & Ortaokul & 45 & 16,2 \\
\hline & Lise & 82 & 29,5 \\
\hline & Üniversite & 55 & 19,8 \\
\hline
\end{tabular}

Tablo 1 incelendiğinde örneklemi oluşturan Çanakkale Onsekiz Mart Üniversitesi Eğitim Fakültesi Illköğretim Bölümü'nde 3. sınıflarda öğrenim gören 278 öğretmen adayının yaklaşık \%40'ının sınıf öğretmenliği öğrencisi olduğu, \%80' inin kız öğrenci olduğu, \%55,4'ünün ikinci öğretim öğrencisi olduğu, \%45'inin 500-1500 TL arası aile gelirine sahip olduğu, \%68' inin ilçe ya da il merkezinde yaşadığı, \%54'ünün annesinin ilkokul mezunu, tamamı okur-yazar babaya sahip öğrencilerin \%20'sinin babasının üniversite mezunu olduğu görülmektedir.

\section{Veri Toplama Aracı}

Araştırmada veri toplama aracı olarak 34 maddeden oluşan kitap okumaya yönelik bir tutum ölçeği kullanılmıştır. Susar Kırmızı (2012) tarafından geliştirilen tutum ölçeğin geçerlik ve güvenirlik çalışması Pamukkale Üniversitesi Eğitim Fakültesi 3. sınıf öğrencileriyle gerçekleştirilmiştir. Ölçekte yer alan maddelerin faktör yük değerleri .80 ile .54 arasında değişmektedir. Ölçeğin Cronbach's Alpha güvenirlik katsayısı da 0,95 olarak belirlenmiştir. 5'li Likert tipinde hazırlanan ölçekte, "katılıyorum", "büyük ölçüde katılıyorum", "orta düzeyde katılıyorum", "pek katılmıyorum", "katılmıyorum" seçeneklerine yer verilirken yapılan bu araştırmada öğretmen adaylarının daha içten ve samimi yanıtlar vermelerini sağlamak amacıyla "katılıyorum", "orta düzeyde katılıyorum" ve "katılmıyorum" şeklinde 3'lü likert derecelemesi kullanılmıştır. Böylece ölçeğin tamamı için alınabilecek azami puan "102 puan" olurken, asgari puan da "34 puan" olmuştur.

3. sınıflarda öğrenim gören öğretmen adayları üzerinde geliştirilen ölçeğin yine 3. sınıflarda öğrenim gören öğretmen adaylarına uygulanması sonucu elde edilen verilerin analizinde toplam ölçek puanları temel alınmıştır. Öğretmen adaylarının kitap okuma alışkanlıklarına yönelik tutumlarının cinsiyete (K-E) ve öğretim türüne (normal öğretim-ikinci öğretim) göre anlamlı bir 
farklılı̆a sahip olup olmadığını ortaya koymak için bağımsız gruplar için t-Testi, anabilim dalı (sınıf öğretmenliği, okul öncesi öğretmenliği, fen bilgisi öğretmenliği), aile geliri (0-500, 501-1000, 10011500, 1501-2500, 2500 TL ve üzeri), yaşanılan yerleşim yeri türü (köy, kasaba, ilçe, il, büyükşehir) ve anne-baba eğitim durumu (okur-yazar değil, ilkokul mezunu, ortaokul mezunu, lise mezunu, üniversite mezunu) değişkenleri için de tek yönlü varyans analizi uygulanmıştır.

\section{Bulgular}

Bu bölümde çalışmanın amacı doğrultusunda üniversite öğrencilerinin okuma alışkanlıklarının bağıı olduğu değişkenler ile kitap okuma tutumlarının tespit edilmesine yönelik hazırlanan ankete verilen cevapların analizi yapılmıştır. Anket katılan öğretmen adaylarının yıllık okudukları kitap sayısı, türü, kitap okuma dönemleri, kitap okuma alışanlıklarını nereden ve nasıl kazandıkları, kitap okuyamama sebepleri gibi farklı değişkenlerin istatistik sonuçlarına yer verilmiştir. Ayrıca katılımcıların cinsiyeti, bölümü, öğrenim türü, ortalama gelir ve anne-baba eğitim durumu gibi değişkenler ile kitap okuma tutum ölçeği puanları arasındaki ilişkinin profilleri ortaya konulmaya çalışılmıştır. Tablo 2 de öğretmen adaylarının okudukları kitap sayısı ve türünü gösteren istatistik verilere yer verilmiştir.

\section{Tablo 2. Öğretmen Adaylarının Bir Yılda Okudukları Kitap Sayısı ve Türü}

\begin{tabular}{|l|r|r|l|r|r|}
\hline Değişken & $f$ & $\%$ & Değişken & $f$ & $\%$ \\
\hline 0 & 5 & 1,8 & Macera-Bilim Kurgu & 76 & 27,3 \\
\hline $1-3$ kitap & 69 & 24,8 & Aşk-Sevgi & 80 & 28,8 \\
\hline $4-7$ kitap & 88 & 31,7 & Dini-Ahlaki & 37 & 13,3 \\
\hline 8-12 kitap & 65 & 23,4 & Kişisel Gelişim & 49 & 17,6 \\
\hline 12 kitap ve üzeri & 51 & 18,3 & Sanat-Kültür & 14 & 5,0 \\
\hline & & & Tarih & 22 & 7,9 \\
\hline Toplam & 278 & 100 & Toplam & 278 & 100 \\
\hline
\end{tabular}

Tablo 2 incelendiğinde öğretmen adaylarının sadece $5^{\prime}$ i bir yılda hiç kitap okumadığını ifade ederken 51'i 12 ve üzeri sayıda kitap okuduğunu belirtmiş̧ir. Öğretmen adaylarının yaklaşık \%80'i bir yılda 1-12 arası kitap okuduğunu ifade etmiştir. Öğretmen adaylarının okudukları kitap türleri incelendiğinde 80'i aşk-sevgi konulu kitapları, 76'sı macera-bilim kurgu kitaplarını, 49' u kişisel gelişim kitaplarını, 37'si dini kitapları, 22'si tarih kitaplarını 14'ü de sanat-kültür konulu kitapları daha çok okuduklarını belirtmiştir.

Tablo 3. Öğretmen Adaylarının Kitap Okumada Tercih Ettikleri Dönem ve Kitap Okuma Alışkanlıklarının Kaynağı

\begin{tabular}{|l|r|r|l|r|r|}
\hline Değişken & $f$ & $\%$ & Değişken & $f$ & $\%$ \\
\hline Sonbahar & 40 & 14,4 & Anne-Baba & 34 & 12,2 \\
\hline Kış & 130 & 46,8 & Kardeş & 13 & 4,7 \\
\hline ilkbahar & 13 & 4,7 & Öğretmen & 52 & 18,7 \\
\hline Yaz & 95 & 34,2 & Akrabalar & 7 & 2,5 \\
\hline & & & Arkadaşlar & 61 & 21,9 \\
\hline & & & Içsel & 111 & 39,9 \\
\hline Toplam & 278 & 100 & Toplam & 278 & 100 \\
\hline
\end{tabular}

Öğretmen adaylarının kitap okudukları dönemler incelendiğinde yaklaşık \%47' sinin kış aylarında, \%34,2'sinin yaz aylarında daha çok kitap okudukları anlaşımıştır. Sonbahar aylarında daha çok kitap okuduğunu belirten öğretmen adayı sayısı 40 iken ilkbahar aylarını seçenlerin sayısı sadece 
13 olmuştur. Öğretmen adaylarının kitap okuma alışkanlıklarının kaynağı incelendiğinde yaklaşık \%40'ının kendiliğinden içsel olarak okuduğunu ifade etmesi dikkat çekicidir. Dışsal etkilerle kitap okuma alışkanlığı edindiğini belirten öğretmen adayları incelendiğinde yaklaşık \%22'si arkadaş etkisini, \%19' u öğretmen etkisini, \%12'si anne-baba etkisini, \%5' i kardeş etkisini ve \%2,5'i de akrabalarının etkisiyle kitap okuma alışkanlığı edindiğini ifade etmiştir.

Tablo 4. Öğretmen Adaylarının Daha Fazla Kitap Okumasını Etkileyen Faktörler

\begin{tabular}{|l|r|r|}
\hline Değişken & $\mathrm{f}$ & $\%$ \\
\hline Yeterince sevmemek & 27 & 9,7 \\
\hline İnternet-TV de zaman geçirmek & 89 & 32,0 \\
\hline Kitapların pahalıı̆ığı & 50 & 18,0 \\
\hline Ekonomik gücün sınırııı̆ı & 13 & 4,7 \\
\hline İstenilen kitaplara yaşanılan yerde ulaşamamak & 21 & 7,6 \\
\hline Ders çalışmak & 78 & 28,1 \\
\hline Toplam & 278 & 100 \\
\hline
\end{tabular}

Öğretmen adaylarının daha fazla kitap okumasını etkileyen faktörlere bakıldığında internet ya da televizyonda zaman geçirmenin öğretmen adaylarının \%32'sinin daha fazla kitap okumasını engellediğini belirtmiştir. \%28'i ders çalışmalarının, \%18'i kitapların pahalı olmasını, \%9,7'si kitap okumayı yeterince sevmemeyi, \%7,6'sı yaşadıkları yerde istedikleri kitaplara ulaşamamalarını, \%4,7'si de ekonomik imkânlarının sınırlı olmasını daha çok kitap okumalarını etkilediğini ifade etmiştir.

Tablo 5. Öğretmen Adaylarının Kitap Okumaya ilişkin Tutumlarının Anabilim Dalına Göre Farklıı̆̆ı İçin Tek Yönlü Varyans Analizi Sonuçları

\begin{tabular}{|c|c|c|c|c|c|}
\hline Varyansın Kaynağı & KT & sd. & $\mathrm{KO}$ & $\mathrm{F}$ & $p$ \\
\hline Gruplar Arası & 6,833 & 2 & 3,416 & \multirow{3}{*}{ 034 } & \multirow{3}{*}{,966 } \\
\hline Gruplar İçi & 27425,545 & 275 & 99,729 & & \\
\hline Toplam & 27432,378 & 277 & & & \\
\hline
\end{tabular}

*1) Sınıf Öğretmenliği 2) Okul Öncesi Öğretmenliği 3) Fen Bilgisi Öğretmenliği

Tablo 5'de ortaya çıkan görüşlere ilişkin betimsel veriler Tablo 6'da sunulmuştur.

Tablo 6. Öğretmen Adaylarının Kitap Okumaya Illişkin Tutumlarının Anabilim Dalına Göre Farklılığı İçin Betimsel Veriler

\begin{tabular}{|l|r|r|r|}
\hline Anabilim Dalı & $\mathrm{N}$ & $\bar{X}$ & $\mathrm{~S}$ \\
\hline Sını Öğretmenliği & 110 & 80,08 & 10,48 \\
\hline Okul Öncesi Öğretmenliği & 96 & 79,71 & 8,33 \\
\hline Fen Bilgisi Öğretmenliği & 72 & 79,87 & 11,15 \\
\hline Toplam & 278 & 79,90 & 9,95 \\
\hline
\end{tabular}

Tablo 5 ve Tablo 6 incelendiğinde öğretmen adaylarının kitap okumaya ilişkin tutumları anabilim dalına göre anlamlı bir farklılık göstermemektedir $\left\{F_{(2-275)}=, 034 ; p>05\right\}$. Sınıf öğretmenliği öğrencilerinin kitap okumaya ilişkin tutumlarının aritmetik ortalaması "80,08", okul öncesi öğretmen adaylarının kitap okumaya ilişkin tutumlarının aritmetik ortalaması "79,71" ve fen bilgisi öğretmen adaylarının kitap okumaya ilişkin tutumlarının aritmetik ortalamasının "79,87" olduğu görülmektedir. Aradaki bu sayısal farklar istatistiksel olarak anlamlı değildir. Azami puan olarak 102 puanın alınabileceği ölçekten her üç anabilim dalı öğrencilerinin de aldıkları puanların yüksek olduğu da dikkat çekmektedir. 
Tablo 7. Öğretmen Adaylarının Kitap Okumaya Ilişkin Tutumlarının Cinsiyete Göre Farklılığı İ̧̧in t-Testi Sonuçları

\begin{tabular}{|l|r|r|r|r|r|r|}
\hline Cinsiyet & $\mathrm{N}$ & $\bar{X}$ & $\mathrm{~S}$ & $\mathrm{sd}$ & $\mathrm{t}$ & $\mathrm{p}$ \\
\hline $\mathrm{K}$ & 224 & 80,70 & 9,14 & & & \\
\cline { 1 - 3 } $\mathrm{E}$ & 54 & 76,57 & 12,32 & 276 & 2,771 &, 006 \\
\hline
\end{tabular}

Ilköğretim öğretmen adaylarının kitap okumaya ilişkin tutumları, cinsiyete göre anlamlı bir farklılık göstermektedir $\left\{\mathrm{t}_{(277)}=2,771 \mathrm{p}<.05\right\}$. Kız öğrencilerin kitap okumaya ilişkin tutumlarının aritmetik ortalaması " 80,70 " iken erkek öğrencilerin kitap okumaya ilişkin tutumlarının aritmetik ortalaması "76,57" olarak gerçekleştirilmiştir. Aradaki bu sayısal farklar istatistiksel olarak anlamlıdır. Yani Çanakkale Onsekiz Mart Üniversitesi Eğitim Fakültesi İlköğretim Bölümü’nde 3. sınıflarda öğrenim gören kız öğrenciler, erkek öğrencilere göre daha yüksek kitap okuma tutumuna sahiptir.

Tablo 8. Öğretmen Adaylarının Kitap Okumaya IIlişkin Tutumlarının Öğretim Türüne Göre Farklılığı Için t-Testi Sonuçları

\begin{tabular}{|l|r|r|r|r|r|r|}
\hline Öğretim Türü & $\mathrm{N}$ & $\bar{X}$ & $\mathrm{~S}$ & $\mathrm{sd}$ & $\mathrm{t}$ & $\mathrm{p}$ \\
\hline Normal Öğretim & 124 & 80,06 & 9,25 & & & \\
\cline { 1 - 1 } íkinci Öğretim & 154 & 79,77 & 10,50 & 276 &, 243 &, 808 \\
\hline
\end{tabular}

Illköğretim öğretmen adaylarının kitap okumaya ilişkin tutumları, öğretim türüne göre ise anlamlı bir farklılık göstermemektedir $\left\{\mathrm{t}_{(277)}=2,771 \mathrm{p}>.05\right\}$. Normal öğretim öğrencilerinin kitap okumaya ilişkin tutumlarının aritmetik ortalaması "80,06", ikinci öğretim öğrencilerinin kitap okumaya ilişkin tutumlarının aritmetik ortalaması ise "79,77" olarak gerçekleşmiştir. Aradaki bu sayısal farklar istatistiksel olarak anlamlı değildir. Yani üniversiteye giriş için yapılan ulusal bir sınavla belirlenen normal öğretim ya da ikinci öğretim olma durumu ile öğrencilerin kitap okumaya ilişkin tutumları arasında anlamlı bir ilişki ortaya çıkmamıştır.

Tablo 9. Öğretmen Adaylarının Kitap Okumaya Iliş̧kin Tutumlarının Aile Gelirine Göre Farklılı̆ı İçin Tek Yönlü Varyans Analizi Sonuçları

\begin{tabular}{|l|r|r|r|r|r|}
\hline Varyansın Kaynağı & KT & sd. & KO & F & $p$ \\
\hline Gruplar Arası & 455,112 & 4 & 113,778 & & \\
\cline { 1 - 4 } Gruplar İ̧i & 26977,266 & 273 & 98,818 & 1,151 & \multirow{2}{*}{333} \\
\cline { 1 - 4 } Toplam & 27432,378 & 277 & & & \\
\hline
\end{tabular}

*1) 0-500 TL 2) 501-1000 TL 3) 1001-1500 TL 4) 1501-2500 TL 5) 2501 TL ve üzeri

Tablo 9'da ortaya çıkan görüşlere ilişkin betimsel veriler Tablo 10'da sunulmuştur

Tablo 10. Öğretmen Adaylarının Kitap Okumaya Ilişskin Tutumlarının Aile Gelirine Göre Farklılığı Için Betimsel Veriler

\begin{tabular}{|l|r|r|r|}
\hline Aile Geliri & N & $\bar{X}$ & $\mathrm{~S}$ \\
\hline $0-500 \mathrm{TL}$ & 32 & 77,62 & 11,00 \\
\hline $501-1000 \mathrm{TL}$ & 62 & 79,82 & 10,52 \\
\hline $1001-1500 \mathrm{TL}$ & 63 & 81,61 & 7,41 \\
\hline 1501-2500 TL & 77 & 80,32 & 10,13 \\
\hline 2501 TL ve üzeri & 44 & 78,47 & 11,04 \\
\hline Toplam & 278 & 79,90 & 9,95 \\
\hline
\end{tabular}


Tablo 9 ve Tablo 10 incelendiğinde öğretmen adaylarının kitap okumaya ilişkin tutumları aile gelirine göre anlamlı bir farklılık göstermemektedir $\left\{F_{(4-273)}=1,151 ; p>05\right\}$. 0-500 TL aile gelirine sahip öğrencilerinin kitap okumaya ilişkin tutumlarının aritmetik ortalaması "77,62", 501-1000 TL aile gelirine sahip öğrencilerinin kitap okumaya ilişkin tutumlarının aritmetik ortalaması "79,82", 1001$1500 \mathrm{TL}$ aile gelirine sahip öğrencilerinin kitap okumaya ilişkin tutumlarının aritmetik ortalaması "81,61", 1501-2500 TL aile gelirine sahip öğrencilerinin kitap okumaya ilişkin tutumlarının aritmetik ortalaması "80,32" ve 2501 TL ve üzeri aile gelirine sahip öğrencilerinin kitap okumaya ilişkin tutumlarının aritmetik ortalamasının ise "78,47" olduğu görülmektedir. Bu sayısal farklar istatistiksel olarak anlamlı değildir. Bununla birlikte 1001-2500 TL arası aile gelirine sahip öğrencilerin kitap okumaya ilişkin tutumlarının diğer öğrencilerden daha yüksek olması da dikkat çekmektedir.

Tablo 11. Öğretmen Adaylarının Kitap Okumaya Ilişskin Tutumlarının Yaşanılan Yerleşim Yerine Göre Farklılığı için Tek Yönlü Varyans Analizi Sonuçları

\begin{tabular}{|l|r|r|r|r|r|}
\hline Varyansın Kaynağı & KT & sd. & KO & F & p \\
\hline Gruplar Arası & 740,038 & 4 & 185,009 & & \\
\cline { 1 - 4 } Gruplar İçi & 26692,340 & 273 & 97,774 & \multirow{2}{*}{1,892} & \multirow{2}{*}{112} \\
\cline { 1 - 4 } Toplam & 27432,378 & 277 & & & \\
\hline
\end{tabular}

Tablo 11'de ortaya çıkan görüşlere ilişkin betimsel veriler Tablo $12^{\prime}$ de sunulmuştur

Tablo 12. Öğretmen Adaylarının Kitap Okumaya İlişkin Tutumlarının Yaşanılan Yerleşim Yerine Göre Farklılığı İçin Betimsel Veriler

\begin{tabular}{|l|r|r|r|}
\hline Yerleşim Yeri & N & $\bar{X}$ & S \\
\hline Köy & 24 & 81,16 & 10,27 \\
\hline Kasaba & 17 & 81,29 & 7,71 \\
\hline ilçe & 99 & 78,82 & 10,54 \\
\hline il & 91 & 78,86 & 9,52 \\
\hline Büyükşehir & 47 & 83,02 & 9,61 \\
\hline Toplam & 278 & 79,90 & 9,95 \\
\hline
\end{tabular}

Tablo 11 ve Tablo 12 incelendiğinde öğretmen adaylarının kitap okumaya ilişkin tutumları yaşanılan yerleşim yerine göre anlamlı bir farklıık göstermemektedir $\left\{F_{(4-273)}=1,892 ; p>05\right\}$. Öğrencilik dışındaki hayatlarında köyde yaşayan öğrencilerinin kitap okumaya ilişkin tutumlarının aritmetik ortalaması "81,16", kasabada yaşayan öğrencilerinin kitap okumaya ilişkin tutumlarının aritmetik ortalaması "81,29", ilçede yaşayan öğrencilerinin kitap okumaya ilişkin tutumlarının aritmetik ortalaması "78,82", ilde yaşayan öğrencilerinin kitap okumaya ilişkin tutumlarının aritmetik ortalaması " 78,86 " ve büyükşehirde yaşayan öğrencilerinin kitap okumaya ilişkin tutumlarının aritmetik ortalamasının ise " 83,02 " olduğu görülmektedir. Aradaki bu sayısal farklar istatistiksel olarak anlamlı değildir. Bununla birlikte büyükşehirde yaşayan öğrencilerin kitap okumaya ilişkin tutumlarının diğer öğrencilerden daha yüksek olması da dikkat çekmektedir.

Tablo 13. Öğretmen Adaylarının Kitap Okumaya Ilişskin Tutumlarının Anne Eğitim Durumuna Göre Farklılığı İ̧in Tek Yönlü Varyans Analizi Sonuçları

\begin{tabular}{|l|r|r|r|r|r|}
\hline Varyansın Kaynağı & KT & sd. & KO & F & p \\
\cline { 1 - 4 } Gruplar Arası & 62,439 & 4 & 15,610 & \multirow{2}{*}{, 156} & \multirow{2}{*}{, 960} \\
\cline { 1 - 4 } Gruplar İçi & 27369,939 & 273 & 100,256 & & \\
\cline { 1 - 4 } Toplam & 27432,378 & 277 & & & \\
\hline
\end{tabular}


Öğretmen adaylarının kitap okumaya ilişkin tutumlarının "Baba Eğitim Durumu" değişkeni için de farkııı̆ına Tek Yönlü Varyans Analizi ile bakılmıştır.

Tablo 14. Öğretmen Adaylarının Kitap Okumaya Ilişkin Tutumlarının Baba Eğitim Durumuna Göre Farklıı̆̆ı Için Tek Yönlü Varyans Analizi Sonuçları

\begin{tabular}{|l|r|r|r|r|r|}
\hline Varyansın Kaynağı & KT & sd. & KO & F & p \\
\hline Gruplar Arası & 238,072 & 3 & 79,357 & & \\
Gruplar İçi & 27194,306 & 274 & 99,249 &, 800 & ,495 \\
\cline { 1 - 5 } Toplam & 27432,378 & 277 & & & \\
\hline
\end{tabular}

Tablo 13 ve Tablo 14 'de ortaya çıkan görüşlere ilişkin betimsel veriler Tablo $15^{\prime}$ de sunulmuştur.

Tablo 15. Öğretmen Adaylarının Kitap Okumaya Ilişskin Tutumlarının Anne-Baba Eğitim Durumuna Göre Farklılığı Için Betimsel Veriler

\begin{tabular}{|l|r|r|r|r|r|r|}
\hline & \multicolumn{3}{|c|}{ Baba Eğitim Durumu } & \multicolumn{3}{|c|}{ Anne Ĕitim Durumu } \\
\cline { 2 - 7 } & $\mathrm{N}$ & $\bar{X}$ & $\mathrm{~S}$ & $\mathrm{~N}$ & $\bar{X}$ & $\mathrm{~S}$ \\
\hline Okur-yazar değil & 0 & 0 & 0 & 17 & 81,35 & 6,89 \\
\hline Illkokul & 96 & 79,68 & 9,16 & 149 & 79,66 & 9,94 \\
\hline Ortaokul & 45 & 81,71 & 10,98 & 40 & 80,52 & 10,97 \\
\hline Lise & 82 & 80,00 & 9,23 & 53 & 79,71 & 10,27 \\
\hline Üniversite & 55 & 78,65 & 11,38 & 19 & 79,68 & 9,92 \\
\hline Toplam & 278 & 79,90 & 9,95 & 278 & 79,90 & 9,95 \\
\hline
\end{tabular}

Tablo 13 incelendiğinde öğretmen adaylarının kitap okumaya ilişkin tutumları anne eğitim durumuna göre anlamlı bir farklılık göstermemektedir $\left\{F_{(4-273)}=, 156 ; p>05\right\}$. Annesi okur-yazar olmayan öğrencilerinin kitap okumaya ilişkin tutumlarının aritmetik ortalaması "81,35", annesi ilkokul mezunu olan öğrencilerinin kitap okumaya ilişkin tutumlarının aritmetik ortalaması "79,66", annesi ortaokul mezunu olan öğrencilerinin kitap okumaya ilişkin tutumlarının aritmetik ortalaması "80,52", annesi lise mezunu olan öğrencilerinin kitap okumaya ilişkin tutumlarının aritmetik ortalaması " 79,71 " ve annesi üniversite mezunu olan öğrencilerinin kitap okumaya ilişkin tutumlarının aritmetik ortalamasının ise "79,68" olduğu görülmektedir. Aradaki bu sayısal farklar istatistiksel olarak anlamlı değildir. Bununla birlikte annesi okur-yazar olmayan öğrencilerin kitap okumaya ilişkin tutumlarının diğer öğrencilerden daha yüksek olması da dikkat çekmektedir.

Tablo 14 incelendiğinde öğretmen adaylarının kitap okumaya ilişkin tutumları baba eğitim durumuna göre de anlamlı bir farklılık göstermemektedir $\left\{F_{(4-273)}=, 800 ; p>05\right\}$. Babası okur-yazar olmayan öğrenci örneklem içerisinde bulunmadığından ortalaması da alınamamıştır. Babası ilkokul mezunu olan öğrencilerinin kitap okumaya ilişkin tutumlarının aritmetik ortalaması "79,68", babası ortaokul mezunu olan öğrencilerinin kitap okumaya ilişkin tutumlarının aritmetik ortalaması "81,71", babası lise mezunu olan öğrencilerinin kitap okumaya ilişkin tutumlarının aritmetik ortalaması " 80,00 " ve babası üniversite mezunu olan öğrencilerinin kitap okumaya ilişkin tutumlarının aritmetik ortalamasının ise " 78,65 " olduğu görülmektedir. Aradaki bu sayısal farklar istatistiksel olarak anlamlı değildir. Bununla birlikte babası ortaokul mezunu olan öğrencilerin kitap okumaya ilişkin tutumlarının diğer öğrencilerden daha yüksek olması da dikkat çekmektedir.

\section{Sonuç ve Tartışma}

İnsan ne kadar çok kitap okursa o kadar çok ufku açılır. Ufku açılan insanda yaşadığı hayata anlam vermekte zorlanmaz, karşılaştığı olay ve durumları çok iyi değerlendirerek onlardan etkilenip zarar görmeyi en aza indirir. Böylece daha anlamlı bir hayat sürmüş olur. Hepimizin belirli bir süre içinde bulunduğu eğitim sisteminin yetmezliğini düşündüğümüzde bir yol ayrımında olduğumuzu söylemek mümkündür. Kitap görünmeyen bir eğitim aracıdır. Onun yollarında kendimizi aramazsak eğitimin yetmezliği içinde bilgi yoksulu olarak hayatımızın sonuna kadar yaşamak zorunda olabiliriz. 
Çalışmanın sonuçları değerlendirildiğinde; öğretmen adaylarının yaklaşık \%58.3'lük kısmının yılda ortalama 0-7 arası kitap okuduğunu göstermektedir. Orta düzey okuyucu dediğimiz 8-12 kitap okuyanların oranı \%23.4 iken, 12 ve üstü kitap okuyanların oranı ise \%18.3'tür. Okuma alışkanlığı olan ve olmayan bireyleri tanımlayabilme amacıyla Amerikan Kütüphaneciler birliğinin belirlediği ölçütler dikkate alındığında (Gürcan, 1999); 1 yılda 21 ve daha fazla kitap okuyan kişi, "çok okuyan"; 1 yılda 620 kitap okuyan kişi, "orta düzeyde okuyan"; 1 yılda 1-5 kitap okuyan kişi, "az okuyan" ve hiç kitap okumayan kişi de "okuyucu olmayan birey" olarak değerlendirilmektedir. Amerikan kütüphaneciler birliğini belirlediği ölçütlere göre öğretmen adaylarının yarısından fazlası az okuyan dediğimiz okuyucu kitlesine karşılık gelmektedir. Çok okuyan kitlenin ise \%20 den az olduğu görülmektedir. Bu sonuca göre, öğretmen adaylarının okuma alışkanlıklarının yeterli düzeyde olmadığı sonucuna varılabilir. Bu yargı, çeşitli araştırmalarla da (Olson ve Gillis, 1983; Dökmen, 1990; Andrews, 1992; Esgin ve Karadağ, 2000; Semerci, 2002; Balcı, 2003; Saracaloğlu, Bozkurt ve Serin, 2003; Saracaloğlu, Karasakaloglu ve Yenice, 2007; Odabas, Odabas ve Polat, 2008; Yılmaz, Köse ve Korkut, 2009; Aslantürk ve Saracaloglu, 2010) desteklenmektedir.

Öğretmen adaylarının okudukları kitap türleri incelendiğinde \%28.8'i aşk-sevgi konulu kitapları, \%27.6'sı macera-bilim kurgu kitaplarını, \%17.6'sı kişisel gelişim kitaplarını, \%13'ü dini kitapları, \%7.9'u tarih kitaplarını ve \%5'i de sanat-kültür konulu kitapları okuduklarını belirtmiştir. Erişkon, Cangil (2008)'in çalışmasında, Almanca öğretmen adaylarının en çok edebi eserleri (\%40), ikinci sırada \%29 ile kişisel gelişim kitaplarını, \% 13 ile bilim kurgu, \%10 ile tarih, \%8 ile felsefe alanında yazı Imış kitapları okudukları tespit edilmiştir. Sınıf öğretmenleri üzerinde gerçekleştirilen bir araştırmada (Ataklı, 2000) katılımcıların haber içerikli dergiler, gazete ve anı içerikli romanlar okudukları saptanmıştır. Yılmaz (2002) tarafından ilköğretim öğretmenleri üzerinde yapılan bir çalışmada da öncelikle katılımcıların gazete okuduğu saptanmıştır. Katılımcıların kitap olarak da güncel yayınları izledikleri, daha çok sanat kitapları (roman, hikâye) okudukları ve \%21'inin de bir dergiye abone olduğu ortaya konulmuştur. Buna göre, ilköğretim öğretmenlerinin öncelikle gazete, roman ve dergi okudukları saptanmıştır. Yine Akça (2008) tarafından yapılan araştırmada Türkçe öğretmenlerinin okumayı en çok sevdikleri kitap türünün roman (\%47) ve deneme (\%19) olduğu ve öğretmenlerin çoğunluğunun düzenli olarak gazete (\%86) ve dergi (\%42) okuduğu saptanmıştır. Buna göre; öğretmen adayları kitap türü olarak en çok aşk, sevgi ve macera-bilim kurgu kitaplarına ilgi duymaktadır. Sanat, kültür ve tarihi kitaplara ise daha az ilgi göstermektedirler. Geçmiş yıllarda yapılan çalışmalarda ise ilköğretim öğretmenlerinin okuduğu kitap türleri öğretmen adaylarına göre farklılık göstermektedir. Bu sonuç öğretmen adaylarının meslek hayatına atıldıklarında kitap tercihlerinin değişebildiğini göstermektedir.

Öğretmen adaylarının kitap okudukları dönemler incelendiğinde yaklaşık \%47' sinin kış aylarında, \%34,2'sinin yaz aylarında daha çok kitap okudukları anlaşılmıştır. Sonbahar aylarında daha çok kitap okuduğunu belirten öğretmen adayı \%14 iken ilkbahar aylarında kitap okuyanların oranı sadece \%4.7'de kalmıştır. Bu sonuç araştırmanın ilginç bulgularından biridir. Özellikle ilkbahar döneminde okuma oranının çok düşük olması öğrencilerin o dönemde bahar şenliklerinin başlaması ve üniversitenin diğer sosyal etkinliklerinin artmasıyla birlikte okuma alışkanlıklarına bir müddet ara verdiğini göstermektedir. Öğretmen adaylarının kitap okuma alışkanlıklarının kaynağı incelendiğinde yaklaşık \%40'ının kendiliğinden içsel olarak okuduğunu ifade etmesi dikkat çekicidir. Dışsal etkilerle kitap okuma alışkanlığı edindiğini belirten öğretmen adayları incelendiğinde yaklaşık \%22'si arkadaş etkisini, \%19'u öğretmen etkisini, \%12'si anne-baba etkisini, \%5' i kardeş etkisini ve \%2,5'i de akrabalarının etkisiyle kitap okuma alışkanlığı edindiğini ifade etmiştir. Myette, 2006, Wilson, 2007, Baccus, 2004 ve Arıcı'nın (2005) çalışmalarında özellikle ilköğretim dönemlerinde öğretmenlerin öğrencilere okuma alışkanlığı kazandırmada önemli bir role sahip olduğunu göstermektedir.

Öğretmen adaylarının kitap okuyamamasını etkileyen faktörlere bakıldığında \%32'sinin internet ya da televizyonda zaman geçirmenin fazla kitap okumasını engellediğini belirtmiştir. \%28'i ders çalışmalarının, \%18'i kitapların pahalı olmasını, \%9,7'si kitap okumayı yeterince sevmemeyi, $\% 7,6$ 'sı yaşadıkları yerde istedikleri kitaplara ulaşamamalarını, \%4,7'si de ekonomik imkânlarının sınırlı olmasını daha çok kitap okumalarını etkilediğini ifade etmiştir. Semerci (2002) tarafından yapılan çalışmada da öğrencilerin ders dışı kitap okumamalarının nedenleri arasında, televizyonun 
cazip olması, kitapların pahalı olması, ders programlarının yüklü olması, okumanın sevilmemesi, yönlendirme olmaması vb. durumlar gösterilmiştir. Yılmaz (2006)'ın sınıf öğretmeni adayları üzerinde gerçekleştirdiği araştırmada, okuma alışkanlığını azaltan nedenlerin ekonomik nedenler (\%41), çalışma nedeniyle zaman bulamama (\%31) ve okuma alışanlığının ilk, orta ve lise eğitimi yıllarında kazandırılamamış olması (\%28) şeklinde sıralandığı belirlenmiştir. Kolaç (2007)'ın çalışmasında sınıf öğretmeni adaylarının kitap okuma sıklıklarını olumsuz yönde etkileyen nedenlerin başında derslerin, sınavların, ödevlerin ve KPSS'nın geldiği belirtmiştir.. Atak vd. (2007) çalışmalarında öğretmenlerin işlerden zaman bulamama(\%39), teknolojinin gelişmesi (\%35), ailevi etkenler (\%11), seviyeli yayınlar bulamama (\%4) ve arkadaş çevresi (\%3) gibi nedenler yüzünden yeterince okuyamadıklarını bulmuşlardır. Araştırmanın sonuçları, öğretmen adayları üzerinde gerçekleştirilen çeşitli araştırmalar (Esgin ve Karadağ. 2000; Saracaloğlu vd, 2003; Saracaloğlu vd, 2006; Saracaloğlu vd. 2007) ile benzer sonuçları göstermektedir.

Kitap okuma alışkanlıkları ve tutumlarının öğretmen adaylarının cinsiyet, bölüm, öğretim türü, anne baba eğitim durumu, yaşadığı yerleşim yerinin özelliği ve ailenin ortalama aylık geliri açısında değerlendirildiğinde, istatistik açıdan sadece cinsiyet faktörüne göre farklılık oluşmuştur. Katılımcıların okuma ilgisi puanlarının cinsiyet açısından istatistiksel olarak anlamlı bir değişim oluşturduğu belirlenmiştir. Bu durum kız öğrenciler lehinedir. Başka bir anlatımla, kızların okuma ilgisi erkek öğrencilerden daha yüksektir. Nitekim yapılan çeşitli araştırmalar sonucunda da (Aral ve Aktaş, 1997; Hall ve Coles, 1999; Coles ve Hall, 2002; Saracaloğlu vd, 2007; Odabaş vd, 2008) kızların okuma ilgilerinin erkeklerden daha yüksek düzeyde olduğu yönünde benzer bulgular elde edilmiştir. Bu bağlamda söz konusu araştırmaların bulguları ile eldeki çalışma bulgusu birbirini destekler niteliktedir. Araştırmaya katılan sınıf öğretmeni adaylarının okuma ilgisi toplam puanları öğretim türü açısından incelendiğinde, istatistiksel olarak anlamlı bir biçimde farklılaşmadığı anlaşılmaktadır. Bu durumda, katılımcıların okuma ilgilerinin öğretim türünden bağımsız olduğu söylenebilir. Nitekim Saracaloğlu vd. (2007) tarafından yapılan araştırmada da öğrencilerin okuma ilgi ve alışkanlıklarında öğretim türü açısından anlamlı bir değişim olmadığı ortaya konulmuştur. Bu yönüyle, sözü edilen araştırma sonuçları eldeki araştırma bulgularını desteklemektedir. Anne baba eğitim durumu ve sosyo-ekonomik açıdan öğretmen adaylarının kitap okuma tutum puanları arasında anlamlı bir farklılık oluşmamaktadır. Çalışmamızın sonucuyla paralellik gösteren araştırmada, Odabaş, v.d (2008), üniversite öğrencilerinin okuma alışkanlıklarının anne baba eğitim durumları ve sosyo-ekonomik özellikler açısında anlamlı bir farklılık oluşturmadığı yönünde görüş bildirmişlerdir.

Çalışmanın sonuçları değerlendirildiğinde kitap okuma oranının ve kültürünün en üst seviyelerde olması gereken üniversite öğrencilerinin, özelliklede meslek yaşamındaki hamuru çocuklar olan öğretmen adaylarının kitap okuma kültür ve seviyelerinin olması gereken düzeyde olmadığı çok açık bir şekilde gözümüze çarpmaktadır. Bu nedenle kitap okumanın sadece boş zamanlarda yapılması gereken bir eylem olmaması gerektiğinin toplum kültürümüze yerleştirilmesi öncelikli hedef olmalıdır.

Özellikle kitap okuma alışkanlığına yönelik tutumların küçük yaşlarda oluştuğu göz önüne alındığında öncelikli olarak bu tutumu oluşturacak olan anne-baba ve özelliklede öğretmenlerin kitap okuma kültürüne olan tutumları daha da önem kazanmaktadır. Öğretmen adayların kitap okuma alışkanlıklarının arttırılması için öncelikli olarak üniversite öğrenimlerine devam ederken almış oldukları ders uygulamalarında, kitap inceleme ve eleştirilerine yönelik ödevler ve projeler verilmelidir. Burada sorumluluk büyük ölçüde eğitim fakültelerinde derslere devam eden öğretim elemanlarına düşmektedir.

Öğretmen adaylarının en az ilgi duydukları bilim, kültür, sanat ve tarih gibi alanlarda okuma heveslerini arttıracak seminerler, konferanslar, kitap tanıtım günleri, edebiyat günleri, bilim şenlikleri, yazar söyleşileri gibi öğrencileri okumaya teşvik edici etkinlikler düzenlenebilir.

Öğrencilerin kitaba ulaşma olanakları göz önüne alındığında, özellikle kitap temin edebilecekleri kütüphanelerin çalışma saatlerinin özellikle ikinci öğretimde okuyan öğrencilerin yararlanabileceği şekilde düzenlenmesi gereklidir. Bununla birlikte üniversite ve fakülte kütüphanelerinin zenginleştirilmesi ve daha işlevsel hale getirilmesi yararlı olacaktır. 


\section{Kaynakça}

Akca, Ç. (2008). Ilköğretim ikinci kademe öğrencilerine kitap okuma alışkanlığı kazandırmada Türkçe öğretmenlerinin rolü. Yayımlanmamış Yüksek Lisans Tezi, İstanbul, Yeditepe Üniversitesi.

Akçamete, G. (1989). Üniversite öğrencilerinin okumalarının değerlendirilmesi. Ankara Üniversitesi Eğitim Bilimleri Fakültesi Dergisi. 22(2), 735-736.

Aksaçlıoğlu, A.G. ve Yılmaz, B. (2007). Öğrencilerin televizyon izlemeleri ve bilgisayar kullanmalarının okuma alışkanlıkları üzerine etkisi. Türk Kütüphaneciliği, 21(1), 3-28.

Andrews, S.V. (1992). Becoming serious writers/readers: Providing encouragement and contexts for learning. Paper presented at the Annual Indiana Teachers Applying Whole Langoage Conference. (Terre Haute, IN, Feb 22, 1992). ERIC ED345230.

Aral, N. ve Aktaş, Y. (1997). Çocukların televizyon ve diğer etkinliklere harcadıkları sürenin incelenmesi, Hacettepe Üniversitesi Eğitim Fakültesi Dergisi, 13, 99-105.

Arıcı, A.F. (2005). Illköğretim ikinci kademe öğrencilerinin okuma durumları, Yayımlanmamış Doktora Tezi, Erzurum, Atatürk Üniversitesi.

Aslantürk, E. ve Saracaloglu, A. S. (2010). Sınıf öğretmenlerinin ve sınıf öğretmeni adaylarının okuma ilgi ve alışkanlıklarının karşılaştııılması. Anadolu Üniversitesi Sosyal Bilimler Dergisi, 11(1), 155-176.

Atak, M., Gündüz, E., Gür, Ü., Dikici, M. ve Yaman Zengin, B. (2007). Kayseri ili Kocasinan ilçesindeki liselerde görev yapan öğretmenlerin okuma konusundaki bilgi, tutum ve davranışları, 16. Ulusal Eğitim Bilimleri Kongresi, 6-7 Eylül 2007 Tokat, 1-8.

Ataklı, A. (2000). Türkiye'de sınıf öğretmenlerinin okuma alışkanlığı üzerine görüşleri. Hacettepe Üniversitesi Eğitim Fakültesi Dergisi, 19, 20-28.

Baccus, A.A. (2004). Urban fourth and fifth grade teachers' reading attitudes and efficacy beliefs: Relationships to reading instruction and to students' reading attitudes and efficacy beliefs. United States: University of Maryland.

Balcı, V. (2003) Ankara'daki üniversite öğrencilerinin boş zaman etkinliklerine katıılımlarının araştııılması, Milli Eğitim Dergisi, 158. http://dhgm.meb.gov.tr/yayimlar/dergiler/Milli_Egitim_Dergisi/158/balci.htm

Benevides, T.L. (2006). Personel reading habits and literacy instruction in pre-service teachers. Canada: Nipissing University.

Coles, M., and Hall, C. (2002). Gendered reading: Learning from children's reading choices, Journal of Research in Reading, 25(1), 96-108.

Dökmen, Ü. (1990). Lise ve üniversite öğrencilerinin okuma becerileri, ilgileri, okuma ve kütüphane kullanma alışkanlıkları. Eğitim Bilimleri Fakültesi Dergisi. 23(2), 394-418.

Dökmen, Ü. (1994) Okuma becerisi, ilgisi ve alışkanlı̆̆ üzerine psikososyal bir araştırma, ìstanbul: MEB Yay.

Duros, I. and Papadopoulos, C. (2009). Effects of a book club intervention on fifth graders' vocabulary, reading habit and attitude. Boston: Boston University

Erişkon Cangil, B. (2008). Okumayı öğretmek - Almanca öğretmen adayı gençlerin okuma ve kütüphane kullanma alışkanlıkları. Gençliğin izdüşümü, Nilüfer Tapan Armağan Kitabı. Yay. Haz. Nilüfer Kuruyazıcı. İstanbul: Multilingual, 293-313.

Esgin, A. ve Karadağ, O. (2000). Üniversite öğrencilerinde okuma alışkanlığı. Popüler Bilim Dergisi. 82, 19-23. Filiz, K. (2004). Gazi Üniversitesi beden eğitimi ve spor yüksekokulunda okuyan öğrencilerin meslekle ilgili okuma ve araştırma alışkanlıkları, Gazi Üniversitesi Eğitim Fakültesi Dergisi, 24(2), 231-242.

Gürcan, H. i. (1999). Okuma alışkanlığı ile kitap yayımcılığının kültürel iletişim ve teknolojisine bağlı sorunları karşısında Türkiye koşulları temelinde bir model önerisi, Eskişehir, Anadolu Üniversitesi Yayınları.

Hall, C. and Coles, M. (1999). Children's reading choices. Routledge.

Janes, J.L.(2008). Families, motivation, and reading: Pre-Adolescent students. lowa State University Pres.

Koç, S. ve Müftüoğlu, G. (2008). Dinleme ve okuma öğretimi. 21 Kasım 2012 tarihinde www.aof.anadolu.edu.tr/kitap/IOLTP/2277/ unite04.pdf adresinden erişildi.

Koçal, E. (2004). Televizyon çocukları uyuşturuyor. 11 Ekim 2012 tarihinde http://arsiv.sabah.com.tr/2004/09/01/cp/yas114-20040821-101.html adresinden erişildi.

Kolaç, E. (2007). Sınıf öğretmeni adaylarının okuyucu profilleri. Anadolu Üniversitesi VI. Ulusal Sınıf Öğretmenliği Ĕ̆itimi Sempozyumu, 27-29 Nisan 2007, 209-214.

Kurulgan, M. ve Çekerol, G. S. (2008). Öğrencilerin okuma ve kütüphane kullanma alışkanlıkları üzerine bir araştırma. Anadolu Üniversitesi Sosyal Bilimler Dergisi, 8(2), 237-258

Lehr, F. (1981). Television viewing and reading. Reading Teacher, 35(2), 230-233.

Mavi, H. F., Çetin, B. (2009). Beden eğitimi öğretmen adaylarııı kitap okumaya ilişkin görüş ve tutumlarının değerlendirilmesi. C.B.Ü. Beden Eğitimi ve Spor Bilimleri Dergisi, 4(1), 1-11. 
Myette, S. (2006). Finding a great read: Book selection strategies for sixth grade silent reading an abstract. United States: Master of Arts in Education, Pacific Lutheran University.

Netherland, J.L.(2004). A Comparison of students' and parents' habits and attitudes toward reading in title I and non-title I schools. United States: East Tennessee State University

Odabaş, H. (2005). Ülkemizde okuma alışkanlığı ve eleştirel okuma. 01.01.2013'de http//www.humanityankara.edu.tr/bilgibelge/ogrelfiles/ho/Ulkmzde_okm_al_ve_el_om.doc.,1-8. adresinden erişildi.

Odabaş, H., Odabaş, Z.Y., ve Polat, C. (2008). Üniversite öğrencilerinin okuma alışkanlığı: Ankara üniversitesi örnegi. Bilgi Dünyası. 9(2):431-465.

Olson, M. W. and Gillis, M. (1983). Teaching reading study skills and course content to preservice teachers. Reading World. 23(2), 124-133.

Ortaş, i. (2007). Kitap okuma alışkanlığı nasıl kazandırılır? Kitap okuru bir toplum muyuz?-2. 12 Ekim 2012 tarihinde http://www.hakimiyetimilliye.org/index.php?news=864 adresinden erişildi.

Saglamtunç, T. (1990). Türkiye'de üniversite kütüphanecilik bölümlerinin 4. sınıf öğrencilerinin özgür (boş) zaman ders dışı okuma alışkanlıkları üzerine bir araştırma. Türk Kütüphaneciliği, 4, 3-21.

Saracaloglu, A.S., Bozkurt, N. ve Serin, O. (2003). Üniversite öğrencilerinin okuma ilgileri ve okuma alışkanlıklarını etkileyen faktörler, Eğitim Araştırmaları Dergisi, 4(12), 149-157.

Saracaloğlu, A. S., Yenice, N. ve Karasakaloğlu, N. (2006). Öğretmen Adaylarının iletişim ve problem çözme becerileri ile okuma ilgi ve alışkanlıkları arasındaki ilişki, III. Uluslararası Öğretmen Yetiştirme Sempozyumu, 4-5 Mayıs 2006, Çanakkale, 1- 23.

Saracaloğlu, A.S., Karasakaloğlu, N. ve Yenice, N. (2007). Öğretmen adaylarının problem çözme becerileri ile okuma ilgi ve alışkanlıkları arasındaki ilişki, VI. Ulusal Sınıf Öğretmenliği Sempozyumu, 27-29 Nisan 2007, Eskişehir, 384-389.

Semerci, Ç. (2002). Türk üniversitelerinde beden eğitimi ve spor bölümü öğrencilerinin okuma alışkanlıkları. Ĕgitim ve Bilim, 27(125), 36-43.

Sever, S. (1997). Türkçe öğretimi ve tam öğrenme. Ankara: Anı Yayıncılık.

Suat, U. (2008). Okuma alışkanlığımızın kültürel altyapısı, Gaziantep Üniversitesi Sosyal Bilimler Dergisi, 7(1), 218-228.

Susar Kırmızı, F. (2012). Öğretmen adaylarının kitap okuma alışkanlığına yönelik tutum ölçeği: Geçerlik ve güvenirlik çalışması. Turkish Studies-International Periodical For The Languages, Literature and History of Turkish or Turkic, 7(3), Summer 2353-2366.

Sünbül, A. M. ve diğ. (2010). Lise öğrencileri kitap okuma alışkanlıkları: Konya ili araştırma raporu. Konya: Selçuk Üniversitesi Matbaası.

Özen, F. (1998). Türkiye'de okuma alışkanlığı ve öğretmenin sorumluluğu. Eğitim Sen Demokratik Eğitim Kurultayı, 2-6 Şubat 1998. 571-590. Ankara: Volkan Matbaası.

Tezcan, M. (1983). Boş zamanlar sosyolojisi. Ankara: Bilgi Yayınevi.

Wilson, B.C. (2007). A Newspaper reading habit in college students: Family newspaper literacy pratices $K-12$ newspaper exposure and civic interest. United States: Tennessee Technological University.

Yalınkılıç, K. (2007) Türkçe öğretmen adaylarının okumaya ilişkin tutum ve görüşleri. Uluslararası Sosyal Araştırmalar Dergisi, 1(1), 225-241.

Yeni Türk Ansiklopedisi. (1985), Ötüken Yayınevi, 5,1876.

Yılmaz, B. (1998). Okuma alışkanlığı sorunu bir enstitü örneği ve Türkiye için öneriler, Türk Kütüphaneciliği, 12(3), 244-251.

Yılmaz, B. (2002). Ankara'da ilköğretim öğretmenlerinin okuma ve halk kütüphanesi kullanma alışkanlıkları üzerine bir araştırma. Türk Kütüphaneciliği, 16(4), 441-460.

Yılmaz, B. (2004). Öğrencilerin okuma ve kütüphane kullanma alışkanlıklarında ebeveynlerin duyarlılığı. Bilgi Dünyası, 5(2), 115-136.

Yılmaz, B., Köse, E. Ve Korkut, S. (2009). Hacettepe üniversitesi ve Bilkent üniversitesi öğrencilerinin okuma alışkanlıkları üzerine bir araştırma. Türk Kütüphaneciliği. 23(1), 22-51. 